\title{
Impacts of conservation tillage on the hydrological and agronomic performance of Fanya juus in the upper Blue Nile (Abbay) river basin
}

\author{
M. Temesgen ${ }^{1,2}$, S. Uhlenbrook ${ }^{1,4}$, B. Simane ${ }^{3}$, P. van der Zaag ${ }^{1,4}$, Y. Mohamed ${ }^{1,4}$, J. Wenninger ${ }^{1,4}$, and \\ H. H. G. Savenije $\mathrm{e}^{1,4}$ \\ ${ }^{1}$ UNESCO-IHE Institute for Water Education, P.O. Box 3015, 2601 DA Delft, The Netherlands \\ ${ }^{2}$ Civil Engineering Department, Addis Ababa Institute of Technology, Addis Ababa University, P.O. Box 380, \\ Addis Ababa, Ethiopia \\ ${ }^{3}$ Institute of Environment and Development Studies, Addis Ababa University, P.O. Box 2176, Addis Ababa, Ethiopia \\ ${ }^{4}$ Delft University of Technology, Faculty of Civil Engineering and Applied Geosciences, Water Resources Section, \\ Stevinweg 1, P.O. Box 5048, 2600 GB Delft, The Netherlands
}

Correspondence to: M. Temesgen (melesse_tem@yahoo.com)

Received: 29 August 2011 - Published in Hydrol. Earth Syst. Sci. Discuss.: 20 January 2012

Revised: 25 September 2012 - Accepted: 24 October 2012 - Published: 21 December 2012

\begin{abstract}
Adoption of soil conservation structures (SCS) has been low in high rainfall areas of Ethiopia mainly due to crop yield reduction, increased soil erosion following breaching of SCS, incompatibility with the tradition of cross plowing and water-logging behind SCS. A new type of conservation tillage (CT) involving contour plowing and the construction of invisible subsoil barriers using a modified Maresha winged "subsoiler" is suggested as a means to tackle these problems as an integral part of the SCS. We investigated the effect of integrating the CT with SCS on the surface runoff, water-logging, soil loss, crop yield and plowing convenience. The new approach of conservation tillage has been compared with traditional tillage (TT) on 5 farmers' fields in a high rainfall area in the upper Blue Nile (Abbay) river basin. Test crops were wheat [triticum vulgare] and tef [eragrostis tef]. Farmers found CT convenient to apply between SCS. Surface runoff appeared to be reduced under CT by 48 and $15 \%$, for wheat and tef, respectively. As a result, CT reduced sediment yield by 51 and $9.5 \%$, for wheat and tef, respectively. Significantly reduced water-logging was observed behind SCS in CT compared to TT. Grain yields of wheat and tef increased by 35 and $10 \%$, respectively, although the differences were not statistically significant apparently due to high fertility variations among fields of participating farmers. Farmers who tested CT indicated that they will continue this practice in the future.
\end{abstract}

\section{Introduction}

In Ethiopia, land degradation has become one of the most important environmental problems, mainly due to soil erosion and nutrient depletion. Coupled with poverty and the fast-growing population, land degradation poses a serious threat to national and household food security. Different literatures show an escalating threat of land degradation particularly in the highlands (Hurni, 1993). Average soil loss rates on croplands have been estimated at $42 \mathrm{tha}^{-1} \mathrm{yr}^{-1}$ but may reach $300 \mathrm{t} \mathrm{ha}^{-1} \mathrm{yr}^{-1}$ in individual fields (Hurni, 1993). Taddesse (2001) estimated annual topsoil loss due to soil erosion in the highlands of Ethiopia, which accounts for $44 \%$ of the total area, to be 1.5 billion $\mathrm{yr}^{-1}$. This, by far, exceeds the natural rate of soil formation. The 2008 report of FAO indicated that during the period 1981-2003, the total land degraded in Ethiopia is estimated to be $297000 \mathrm{~km}^{2}$ (Bai et al., 2008). Moreover, excessive surface runoff impacted downstream water users through a modified flow regime leading to drying up of springs during the dry season (Bewket and Sterk, 2005; Musefa, 2007). It is estimated that the transboundary rivers that originate from Ethiopian highlands carry about 1.3 billion $\mathrm{tyr}^{-1}$ of sediment to neighboring countries (MoWR, 1993), whereas the Blue Nile alone carries 131 million $\mathrm{yr}^{-1}$ (Betrie et al., 2011) and 61 million $\mathrm{yr}^{-1}$. Poor watershed management and inappropriate farming practices have contributed to these escalating rates. 
In order to reduce soil erosion, a number of soil conservation technologies have been introduced. Soil conservation technologies are generally classified as physical (mechanical) and biological measures. Physical measures include soil bunds and fanja juus (trenches following contour lines with soil bunds at the upslope side; e.g. Makurira et al., 2010). The Ethiopian government launched a massive soil conservation program beginning in the mid-1970s. However, by 1990, only limited SCS survived, viz: $30 \%$ of soil bunds, $25 \%$ of the stone bunds, $60 \%$ of the hillside terraces, $22 \%$ of land planted in trees, and $7 \%$ of the reserve areas still exist (USAID, unpublished data).

Investment in soil conservation structures is expected to lower soil erosion rates and increase grain yields in moisture stressed areas (Makurira et al., 2010; Herweg and Ludi, 1999). But for high rainfall areas, adoption of the technology has been hindered because of reduction in grain yield, accelerated soil erosion, waterlogging behind bunds and incompatibility with the tradition of cross plowing, among others (Shiferaw and Holden, 1999; Herweg, 1993; Hengsdijk et al., 2005).

Farmers often complain that the structures interfere with traditional practices of cross-plowing, especially when the distance between bunds is short, making turning of the plow difficult (Shiferaw and Holden, 1999). Cross-plowing is practiced because the traditional ard plow in Ethiopia, called Maresha, cannot be efficiently used over the same line of plowing in consecutive tillage operations (Temesgen et al., 2008). Therefore, any two consecutive tillage operations have to be carried out perpendicular to each other, which is called cross-plowing. Cross plowing increases surface runoff as a result of plowing up and down the slope, which has also been demonstrated elsewhere (Rowland, 1993). Increased surface runoff leads to either detention of too much water at the bunds leading to waterlogging or breaching of the bunds leading to accelerated soil erosion downstream.

One way of tackling the problem of breakdowns of bunds is to reduce the surface runoff reaching the structures by introducing conservation tillage. Conservation agriculture (CA) was introduced as a concept for resource-efficient agricultural crop production based on an integrated management of soil, water and biological resources combined with external inputs (FAO, 2008). To achieve this, CA is based on three principles: (1) minimum or no mechanical soil disturbance; (2) permanent organic soil cover (consisting of a growing crop or a dead mulch of crop residues); and (3) diversified crop rotations.

However, direct application of these practices of CA is constrained by several technical and socio-economic factors such as the need for dry season animal feed, high costs of herbicide (more expensive than oxen powered mechanical weed control but cheaper than tractor powered mechanical tillage), among others (Temesgen, 2007). Therefore, conservation tillage has been adapted to the local conditions by achieving the objectives but not necessarily by undertaking the suggested practices of CA.

Thus, a conservation tillage system (CT) that involves contour plowing and subsoiling has been developed together with a modified Maresha plow (MST, 2008), which is now available at a price of 20USD. Subsoiling increases infiltration by disrupting plow pans (e.g. Busscher et al., 2002). The formation of plow pans under the traditional cultivation system has been reported (Biazin et al., 2011; Temesgen et al., 2008). Maresha modified subsoilers have been found to effectively disrupt the plow pan resulting in increased infiltration (Temesgen et al., 2009; McHugh et al., 2007).

It is hypothesized that the application of the new tillage system may improve the performance of the soil conservation structures by reducing surface runoff reaching those structures. As such it will reduce water-logging behind SCS, which in turn reduces soil erosion, as well as making it more convenient to plow between SCS because there is no longer a need for cross-plowing. Better moisture distribution between the upper and lower parts of the plot as well as along the soil profile with increased infiltration coupled with enhanced root growth is also expected to increase grain yield.

Therefore, the objective of this study is to assess the hydrological and agronomic impacts of integrating CT with SCS. Specifically, the study investigates the effects of CT on surface runoff and water-logging behind SCS, soil moisture pattern, convenience of plowing between SCS, rate of soil erosion and changes in crop yields as compared to TT.

\section{Materials and methods}

\subsection{Study site}

The experiment was carried out at Enerata $\left(10^{\circ} 24.85^{\prime} \mathrm{N}\right.$, $37^{\circ} 44.92^{\prime} \mathrm{E}$ ) in the upper Blue Nile (Abbay) River basin (Fig. 1). Enerata is located $7 \mathrm{~km}$ North of Debre Markos town, which is about $300 \mathrm{~km}$ North West of Addis Ababa. The altitude ranges from 2380 to $2610 \mathrm{~m}$. The study area is characterized by sub-humid climatic condition and typically represents the "Dega" zone of the traditional agro-climatic classification system of Ethiopia. The mean annual rainfall and temperature are $1300 \mathrm{~mm} \mathrm{yr}^{-1}$ and $15^{\circ} \mathrm{C}$, respectively, as recorded by Debre Markos weather station. The rainfall is unimodal occurring mainly in the months of June to September (locally known as "kiremt" season). The driest months are November to February (locally known as "bega" season).

The study area is a part of the highlands that largely owe their altitude to the uplift of the Arabo-Ethiopian land mass. The soil type in the study area is mainly Nitosols while the textural class is clay loam. The soil texture is uniform over the $0-60 \mathrm{~cm}$ layer. Soil porosity in the area is on average 0.55 . The prevalent farming system in the study area is a subsistence mixed crop-livestock system, typical for the highlands of the country, where livestock provide the draught 


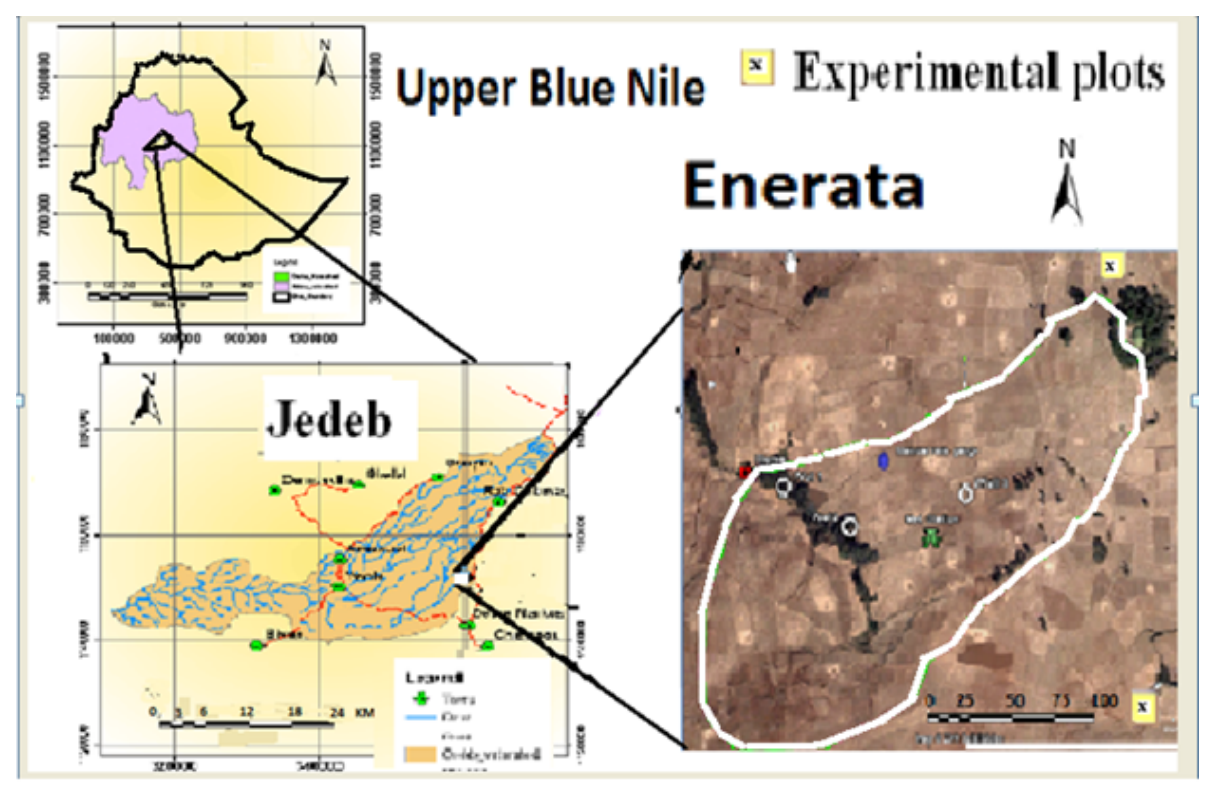

Fig. 1. Study sites at Enerata. Predominantly cultivated area in the mid-altitudes of the Choke Mountains, headwaters of the Blue Nile river basin. Source of Satellite picture is Google Earth (2009).

power needed for the farming operation and a good part of crop residues are fed to livestock. The main types of crops cultivated in the study area are barley (Hordeum vulgare), engido (Avena spp.), wheat (Triticum vulgare) and tef (Eragrostis tef). Tef, very popular in Ethiopia, is an annual cereal crop (belonging to the grass family) that has a very low canopy cover. Tef has very fine seeds that require repeated plowing of fields to prepare fine seedbeds and to control weeds, which increases the vulnerability of the soil to erosion.

\subsection{Experimental setup}

Five farmers were selected and trained on the concepts and field applications of CT in addition to supervision during field works out of which four were involved in the experiment. The experimental set up was first explained to and discussed with the farmers. Each participating farmer was provided with a winged subsoiler. They were advised to keep notes of what they observed throughout the season. All other inputs such as fertilizer and seeds were provided by farmers themselves. Fertilizer rates applied to all plots followed the recommendations. Di-Ammonium Phosphate (DAP) at a rate of $100 \mathrm{~kg} \mathrm{ha}^{-1}$ containing $46 \%$ Nitrogen, $23 \%$ Phosphorus and $21 \%$ Potassium was applied at sowing while Urea containing $100 \%$ Nitrogen was applied at a rate of $50 \mathrm{~kg} \mathrm{hs}^{-1}$ 35 days after sowing. An agreement was made with farmers such that if a CT plot gave lower yield than that of TT, the research project would pay the difference. Farmers were encouraged to make cross visits of their fields and discuss among themselves about the performance of CT. A meeting was held with farmers after they harvested the crop to discuss the results of the experiment.

Locally adapted conservation tillage has been tested in comparison with the traditional tillage system. CT involved contour plowing, subsoiling and leaving invisible barriers parallel to furrows (Fig. 2c). CT employed a Maresha modified winged subsoiler (Fig. 2b), which made it possible to undertake contour plowing while disrupting the plow pan below the depth of operation of the Maresha. Farmers started with contour plowing using Maresha followed by subsoiling the same furrows.

During the third pass, Maresha was used along the same lines to make the furrows wider and more visible for the next subsoiling. The CT system left invisible subsurface barriers, in each furrow which hindered flow along the slope thereby facilitating slow drainage parallel to the structures, increasing infiltration and percolation thus protecting the soil conservation structures.

The experiment was laid out in a randomized complete block design (RCBD) with 4 replications (4 farmers) and 2 treatments (CT and TT). All experimental fields were treated with Fanya juus as part of the routine soil conservation works of the local Bureau of Agriculture. Two field segments each bounded by Fanya juus were selected from each of the 4 farmers such that they have similar slopes, which ranged between 9 and $11 \%$. 


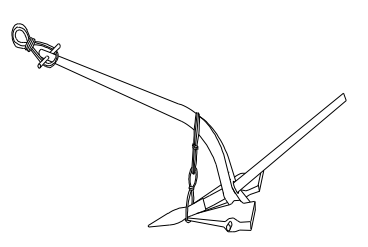

(a)

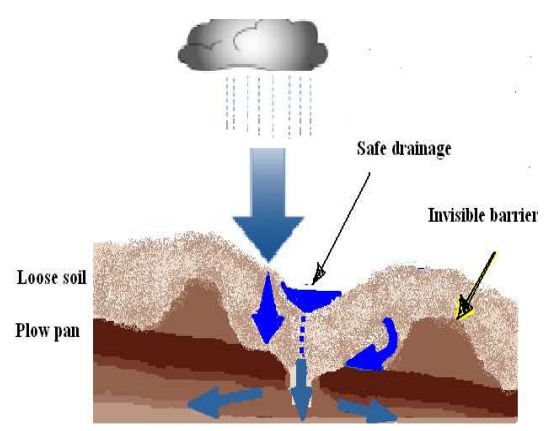

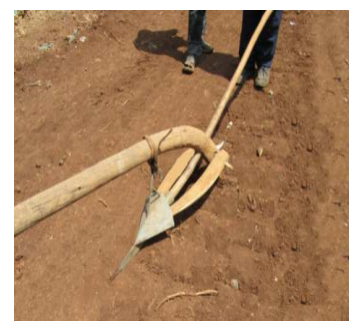

(b)

Fig. 2. (a) The traditional plow in Ethiopia, Maresha and (b) winged subsoiler. The winged subsoiler has a vertical share and wings with sharp edges (MST, 2008). (c) Schematic representation of the new conservation tillage system whereby surface runoff is reduced, allowing more infiltration through the disrupted plow pan and redirecting flow along the contour by the invisible barriers.

\subsection{Field measurements}

\subsubsection{Testing soil compaction and soil profile}

Soil penetration resistance was measured at 15 randomly selected sites in traditionally cultivated fields in Enerata. A penetrologger (Eijkelkamp ${ }^{\circledR}$ ) was used for the study. The speed of operation was adjusted to $2 \mathrm{~cm} \mathrm{~s}^{-1}$ while a $1 \mathrm{~cm}^{2}$ area $30^{\circ}$ cone was used for ease of penetration into the lower compacted layers. The soil profile over the plow depth was assessed by measuring the distance from a horizontal line to the undisturbed surface both before and after tillage. Two pegs, spaced $1.6 \mathrm{~m}$ apart, were placed across the tillage direction. A rope was tied to the two pegs. In the upslope peg, the knot was placed $5 \mathrm{~cm}$ above the ground. The rope was kept level while tying it to the down slope peg. Height of the rope from the ground was measured at $10 \mathrm{~cm}$ interval before tillage. CT was applied without removing the pegs. Then the lose soil between the two pegs was carefully removed by hand. The rope was again tied to the two pegs and height of the rope from the undisturbed soil was measured at every point where the soil profile changed.

\subsubsection{Agronomic data}

Plant population, plant height, biomass and grain yield were measured. Samples for biomass and grain yield were taken from 5 sites in each plot. A $1 \mathrm{~m} \times 1 \mathrm{~m}$ frame was used to delineate the area for sample collection. The samples from the 5 sites in each plot were mixed and weighed in the field after drying. The grain was then manually threshed and put in plastic bags. The grain samples were weighed using electronic balances in the lab and the weights were adjusted for a moisture content of $14 \%$.

\subsubsection{Hydrological and meteorological data}

Soil moisture contents were continuously monitored in both TT and CT. Moisture sensors (10HS soil moisture sensors, $\mathrm{CaTec}^{\circledR}$ ) were installed at $0-15$ and $15-30 \mathrm{~cm}$ depths in each plot (both wheat and tef and CT and TT). Sensors were permanently installed in four plots where full instrumentations were made. Measurements were made on soil moisture in the root zone in the lower parts of each plot bounded by two consecutive SCS in CT as well as TT. Measurement intervals were $5 \mathrm{~min}$. Equation (1) was used to convert the raw readings into soil moisture content as $\%$ vol.

$\Theta=0.00085 \times$ RAW -0.481

where RAW is the reading taken from the sensors and $\Theta$ is the soil moisture content as $\%$ vol.

Runoff measurements were made from $5 \mathrm{~m} \times 30 \mathrm{~m}$ plots delineated inside each field segment (Fig. 3a), The three sides were fenced with galvanized iron sheets while the lower side was bounded by the Fanya juus. The iron sheets were inserted $15 \mathrm{~cm}$ deep while remaining $10 \mathrm{~cm}$ above the surface. Delineation of the plots was carried out immediately after sowing. The dates and number of tillage operations in both 

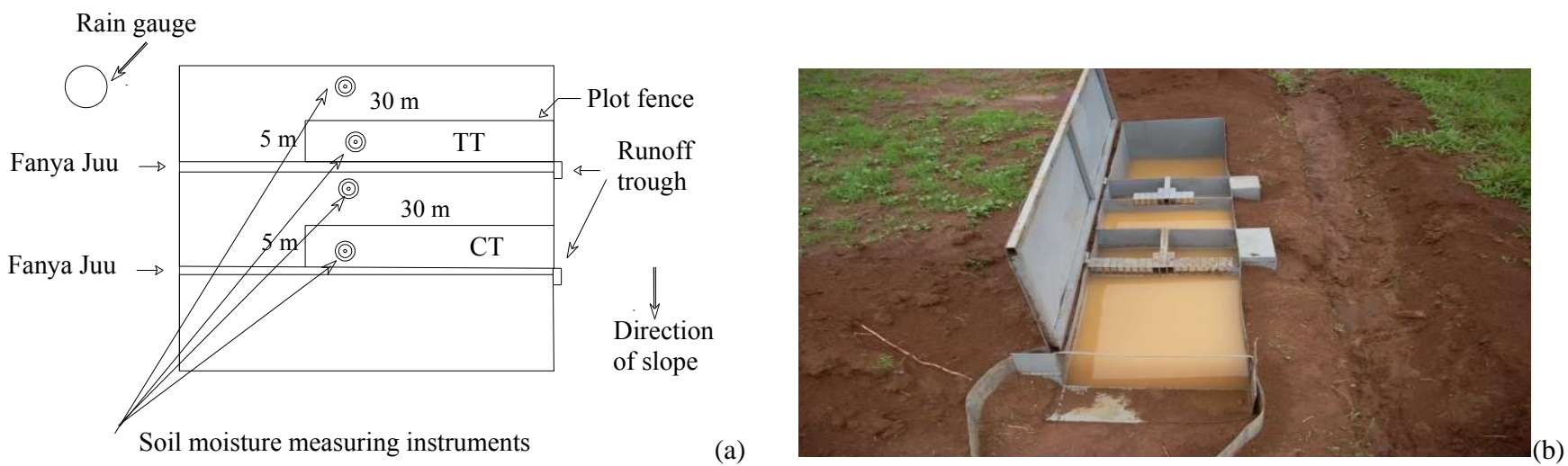

Fig. 3. (a) Layout of a single replication (one farmer's field). The three sides of the $5 \mathrm{~m} \times 30 \mathrm{~m}$ area is bound by a galvanized iron sheet fence that was inserted $15 \mathrm{~cm}$ in to the soil with $10 \mathrm{~cm}$ height above the ground. The lower side is bound by the Fanya juu. Runoff was collected from this area. Locations of CT and TT were randomly selected for each block. (b) Runoff trough used in the study. The picture was taken following a high rainfall day on 31 August 2010. About $2 \mathrm{~m}^{3}(13 \mathrm{~mm})$ of runoff was recorded by the trough from a $36 \mathrm{~mm} \mathrm{~d}^{-1}$ rainfall event on a field with TT wheat.

treatments of each farmer (replication) were made the same. All farmers plowed wheat fields 4 times before sowing while that number was 5 for tef.

Runoff measuring troughs (Fig. 3b) were designed, fabricated and installed at the lower corners of 4 plots (two with tef and two with wheat). The trough is divided into three main compartments. The first part retains the whole runoff until it is full. Once it reaches its capacity excess runoff is spilled through 20 pipes welded at the top of the lower side of the compartment. One of the 20 pipes is extended to deliver $5 \%$ of the excess runoff to the second main compartment, which again spills through 10 pipes out of which one is extended to sample $10 \%$ of the remaining excess runoff. Thus, the trough can handle up to $18 \mathrm{~m}^{3} \mathrm{~d}^{-1}$ of runoff, which is equivalent to the maximum daily rainfall expected to occur once in $10 \mathrm{yr}\left(85 \mathrm{~mm} \mathrm{~d}^{-1}\right.$ as recorded in Debre Markos weather station) with a $50 \%$ runoff coefficient from a $400 \mathrm{~m}^{2}$ plot, the largest plot size in this experiment.

Sediment yield was determined as the sum of bed load and suspended load. The volume of bed load trapped in the runoff trough was determined by measuring the depth of deposited soil at four corners of the trough daily at 09:00 a.m. UTC+03:00. Suspended load was estimated based on samples collected from the second and third compartments, after thoroughly mixing the stored water. Soil loss within the plot was determined by measuring the heights of pegs installed at randomly selected points in each plot. Increased peg height shows erosion while reduced height shows deposition.

An automatic meteorological station was installed near the experimental plots. The equipment recorded rainfall, temperature, relative humidity and sunshine duration every $5 \mathrm{~min}$. A manual raingauge was installed near the experimental plots for daily measurement of rainfall.

\subsection{Data analysis}

Analysis of variance was made using the General Linear Model (GLM) procedure in SPSS version 15.0 for windows (Julie, 2007). Mean separation was made using the Tukey's Honestly Significant difference test. Comparisons of the mean biomass and grain yields were made on CT and TT using the independent sample t-test $(\alpha=0.05)$. In addition, data from only 2 replications were analyzed using simple descriptive statistics. Time series analysis on soil moisture dynamics and daily runoff were also carried out.

\section{Results and discussion}

\subsection{Plow pans}

Field tests carried out in the Choke Mountains indicate significant soil compaction revealing the formation of plow pans. Figure 4 shows penetration resistance values along the profile of cultivated soils at Enerata. A sharp rise in penetration resistance is evident below $10 \mathrm{~cm}$ reaching its maximum at about $20 \mathrm{~cm}$, which is a typical plow pan for shallow tillage. Field observation of bulk density showed an increasing compaction with depth. Plow pan formation under Maresha cultivation has been found elsewhere in Ethiopia with its peak located at a depth of $18-20 \mathrm{~cm}$ (Biazin et al., 2011; Temesgen et al., 2008).

\subsection{Soil profile}

Figure 5 shows the undisturbed soil profiles before and after conservation tillage. The area shaded in light brown is the plowed layer while the dark brown area represents the undisturbed layer. The average distance between the furrows is about $20 \mathrm{~cm}$. Plowing up and down the slope in TT resulted in straight horizontal soil layer differentiated by a sharp line, 


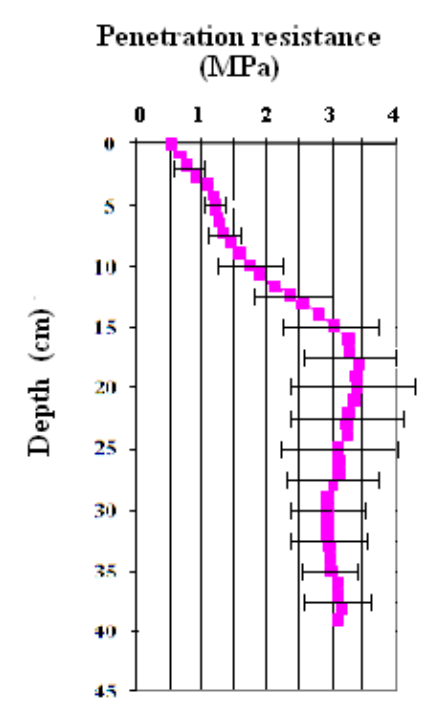

Fig. 4. Soil compaction at Enerata. Rise in penetration resistance starts at $10 \mathrm{~cm}$, which is the average depth of operation of the Maresha plow. The resistance peaks at $20 \mathrm{~cm}$ depth. Each point is the average of ten readings.

which led to accelerated flow in TT preferentially in the furrows that are laid along the slope. Since the soil below the plow depth is less permeable, the shallow layer becomes quickly saturated and runoff is initiated at the bottom. This also causes landslides depending on the slope of the land, and the less permeable undisturbed soil serves as slip surface. However, after applying CT narrow deep trenches are made along the contour that slow down the movement of water along the slope (Fig. 5) resulting in the fill and spill flow process (Spaaks et al., 2009; Tromp-van Meerveld and McDonnell, 2006). This reduces surface runoff and soil erosion and facilitates deep percolation of soil moisture.

\subsection{Soil moisture}

The soil moisture measurements had been taken continuously at the lower and upper sides of each plot, for a period of one month only (due to vandalism). Although the measurement period is short, the sample results clearly reveal that soil moisture in TT (average $34.6 \%$ vol.) is significantly higher $(\alpha=0.05)$ than that of CT (average $31 \%$ vol.) at 0 $15 \mathrm{~cm}$ depth while the reverse holds true at $15-30 \mathrm{~cm}$ layer (33.5 and $31.6 \%$ vol.), in CT and TT, respectively (Table 1 and Fig. 6). The same trend has been observed both for the upper and lower sides of the plots (Table 1). This is due to increased infiltration in CT compared to TT. Higher temporal variations in CT corresponds to better drainage as the soil responds to rainfall events with a rise in soil moisture followed by quicker drainage. This indicates better aeration as larger pore spaces were occupied by air in CT compared to TT. The sharp peaks in CT show that it remained unsaturated for most of the time. The pore spaces in TT were probably
Table 1. Mean soil moisture content at different layers in response to traditional and conservation tillage in wheat at Enerta, Ethiopia.

\begin{tabular}{llll}
\hline \multirow{2}{*}{ Depth $(\mathrm{cm})$} & Location in & \multicolumn{2}{c}{ Average soil moisture (\% vol.) } \\
\cline { 3 - 4 } & the plot & $\mathrm{TT}$ & $\mathrm{CT}$ \\
\hline $0-15$ & Upper side & $31.27( \pm 0.48) \mathrm{by}$ & $30.37( \pm 0.67) \mathrm{ax}$ \\
& Lower side & $34.61( \pm 0.30) \mathrm{bx}$ & $33.11( \pm 0.66) \mathrm{ay}$ \\
\multirow{2}{*}{$15-30$} & Upper side & $29.42( \pm 0.90) \mathrm{ax}$ & $32.17( \pm 0.32) \mathrm{bx}$ \\
& Lower side & $31.59( \pm 0.21) \mathrm{ay}$ & $33.51( \pm 0.28) \mathrm{by}$ \\
\hline
\end{tabular}

Mean values followed by dissimilar letters $(\mathrm{a}-\mathrm{b})$ across a row and letters $(\mathrm{x}-\mathrm{y})$ along a column with in a depth are significantly $(\alpha=0.05)$ different.

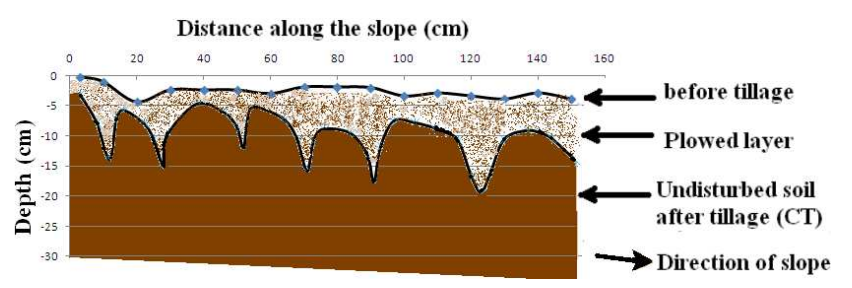

Fig. 5. Typical profiles of soil before and after the application of conservation tillage (CT). The rugged profile of the undisturbed soil beneath the plowed layer creates fill and spill type of subsurface flow. In contrast, traditional cross plowing results in sharp horizontal profile of furrow bottoms that are laid along the slope, at about $10 \mathrm{~cm}$ depth, thus leading to increased flow momentum and soil erosion.

clogged by settling fine particles from standing water at the lower side of the plot. As a result, the air filled pore space would be less in TT than in CT leading to the negative effects of water-logging. Farmers too observed the difference in infiltration rates and the waterlogging behind SCS under TT.

Unlike the upper layers CT resulted in higher soil moisture at $30 \mathrm{~cm}$ depth, i.e. below the plow pan (Fig. $6 \mathrm{~b}$ ). The high temporal variation in soil moisture at $30 \mathrm{~cm}$ depth shows deeper infiltration in CT than in TT, thus making more water available at lower depths in case there is a dry spell. This would also make more water available to roots growing deeper than $30 \mathrm{~cm}$. Further deep percolation is also desirable as it recharges groundwater. It should also be noted that the differences in soil moisture content in the 0-15 and 15-30 cm layers are not so much but the difference in the soil moisture dynamics is an indicator of a higher flux along the profiles of CT plots thus higher percolation in CT than in TT. More surface evaporation in TT from sustained higher soil moisture in the upper layers must have closed the water balance.

\subsection{Surface runoff}

Results of surface runoff for CT and TT are shown in Fig. 7, for two crops: wheat and tef. As can be seen, more surface runoff occurred for TT compared to CT, and that the differences between the two is more in the wheat plot than in 

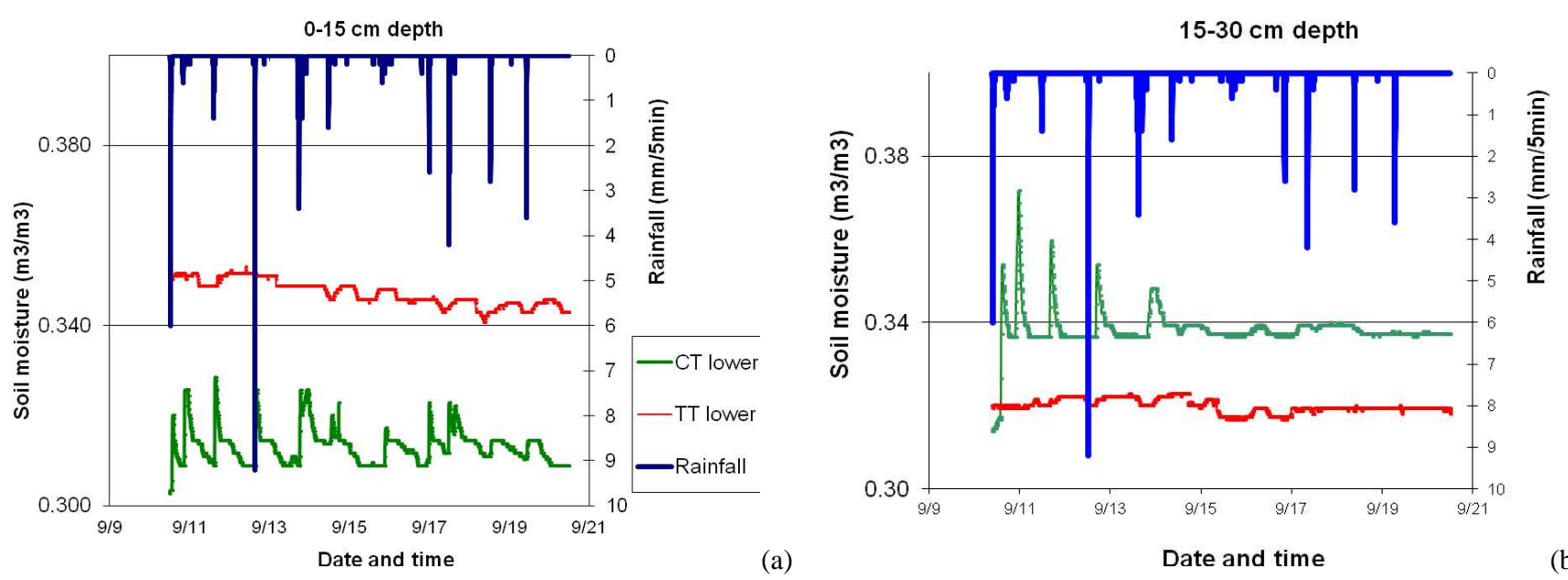

Fig. 6. Soil moisture in TT and CT plots (a) $0-15 \mathrm{~cm}$ depth and (b) $15-30 \mathrm{~cm}$ layer.

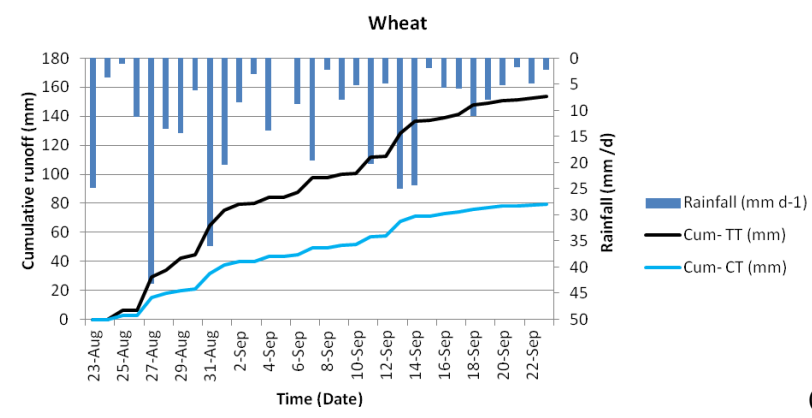

(a)

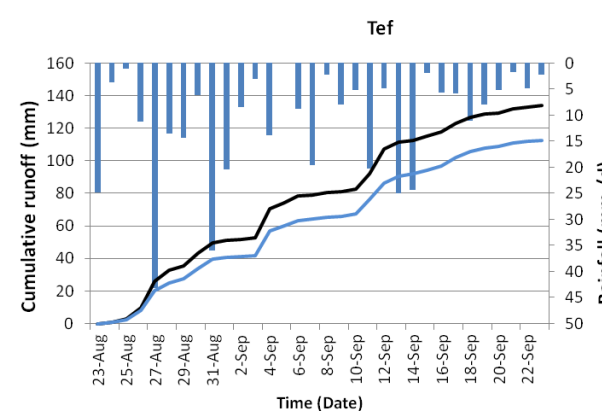

Rainfall (mm d-1)

- Cum- $T$ T $(\mathrm{mm})$ - Cum- CT (mm)

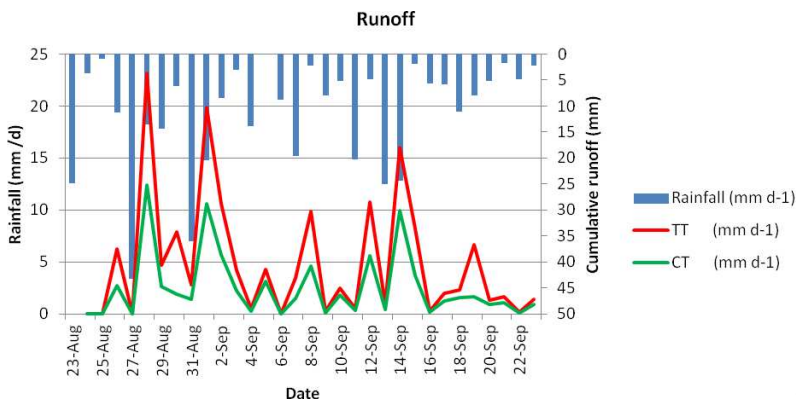

(c)

Fig. 7. Runoff in TT and CT plots of (a) wheat, (b) tef and (c) individual rainfall events and runoff in wheat. tef. The average reduction of surface runoff was $48 \%$ in the wheat plot due to the application of $\mathrm{CT}$, with daily averages of 4.8 and $2.5 \mathrm{~mm} \mathrm{~d}^{-1}$ in TT and CT, respectively. In tef the surface runoff reduction was $15 \%$ with an average of 4.5 and $3.8 \mathrm{~mm} \mathrm{~d}^{-1}$ in TT and CT, respectively. Looking at the individual events it can be observed in Fig. 7 that large rainfall events produced different surface runoff in both treatments, whereas the parallel curves corresponding to small rainfall events indicate little or no difference between treatments. Individual rainfall events and the corresponding surface runoff are also shown in Fig. 7c in which large rainfall events produced large difference in surface runoff, whereas small events did not even produce noticeable surface runoff in both TT and CT. This is due to threshold function meaning the proportion of the initial abstraction became significant in small events thus undermining treatment effects, whereas once the threshold level is exceeded more surface runoff was generated in TT than in CT. The threshold level corresponded to the shallow cultivated layer above the plow pan, which is the same for both treatments. But once this storage is filled deeper infiltration through the disrupted plow pan in CT allowed more infiltration and hence less surface runoff than in TT.

A combination of hydrological processes caused reduction of surface runoff in CT, including the effect of subsoiling, contour plowing and the presence of invisible barriers. Subsoiling disrupted the plow pan thereby enhancing infiltration, the contour plowing with invisible barriers prevented water movement along the slope thereby reducing surface runoff. This result is in agreement with other investigations in similar environments: Sojka et al. (1993) and Harris et al. (1993) and others reported significant reduction in surface runoff as a result of subsoiling, while Gebreegziabher et al. (2009) reported benefits of contour plowing in reducing surface runoff. The differences in surface runoff between CT and TT are larger for wheat than for tef (Table 2). This 
Table 2. Runoff sediment concentration and total soil loss of the different farm plots during (23 August to 24 September 2010 at Enerata).

\begin{tabular}{lcll}
\hline Crop type & Treatments & $\begin{array}{l}\text { Average } \\
\text { suspended } \\
\text { sediment } \\
\text { concentration } \\
\left(\mathrm{gm} \mathrm{l}^{-1}\right)\end{array}$ & $\begin{array}{l}\text { Total soil loss } \\
\left(\mathrm{t} \mathrm{ha}^{-1} \mathrm{month}^{-1}\right)\end{array}$ \\
& & $3.46( \pm 0.80) \mathrm{a}$ & $8.55( \pm 1.31) \mathrm{a}$ \\
\hline Wheat & $\mathrm{TT}$ & $3.21( \pm 0.53) \mathrm{a}$ & $5.41( \pm 0.87) \mathrm{b}$ \\
& $\mathrm{CT}$ & $3.11( \pm 0.54) \mathrm{a}$ & $11.76( \pm 1.95) \mathrm{a}$ \\
Tef & $\mathrm{TT}$ & $3.02( \pm 0.59) \mathrm{a}$ & $10.73( \pm 1.85) \mathrm{a}$ \\
\hline
\end{tabular}

is because farmers let animals trample on tef seedbed during sowing for better seed-soil contact, which is crucial for germination and establishment of the small seeded crop (Teklu and Gezahegn, 2003). As a result, the compacted surface reduces infiltration, and thus undermining treatment effects. Unfortunately, surface runoff could only be monitored after sowing. Future moisture measurements should start before sowing, since treatment effects could be significant before the sowing of tef (before seedbed compaction).

It can be noted that the difference in soil moisture content between CT and TT in the upper layers of the lower sides of the plots is not so large as that in surface runoff. This is due to the threshold effect as the soil moisture could not increase beyond the saturation level, whereas the surface runoff continued to occur depending on the amount and duration of the rainfall.

\subsection{Water-logging behind Fanya juus}

Figure $8 \mathrm{a}$ and $\mathrm{b}$ show wheat crops behind Fanya juus under CT and TT, respectively. The wheat crop under CT showed vigorous growth and greener stand while that under TT turned yellow with stunted growth. CT resulted in less surface runoff thereby reducing surface runoff, which reaches Fanya juus. Moreover, disrupted plow pans in CT apparently facilitated better drainage thus avoiding waterlogging behind bunds.

\subsection{Sediment yield}

Results of sediment yield observations (both suspended and bed load) are shown in Table 1 and Fig. 9. The results demonstrate reduced sediment yield in both wheat and tef due to the application of CT. Reduced surface runoff in CT led to reduced soil erosion. Other investigators (Sojka et al., 1993) have reported similar results. Farmers too noticed the differences in soil loss due to tillage treatments. The differences between CT and TT are larger for wheat than for tef. This is caused by seedbed compaction carried out during sowing of tef which undermined treatment effects in the same way as
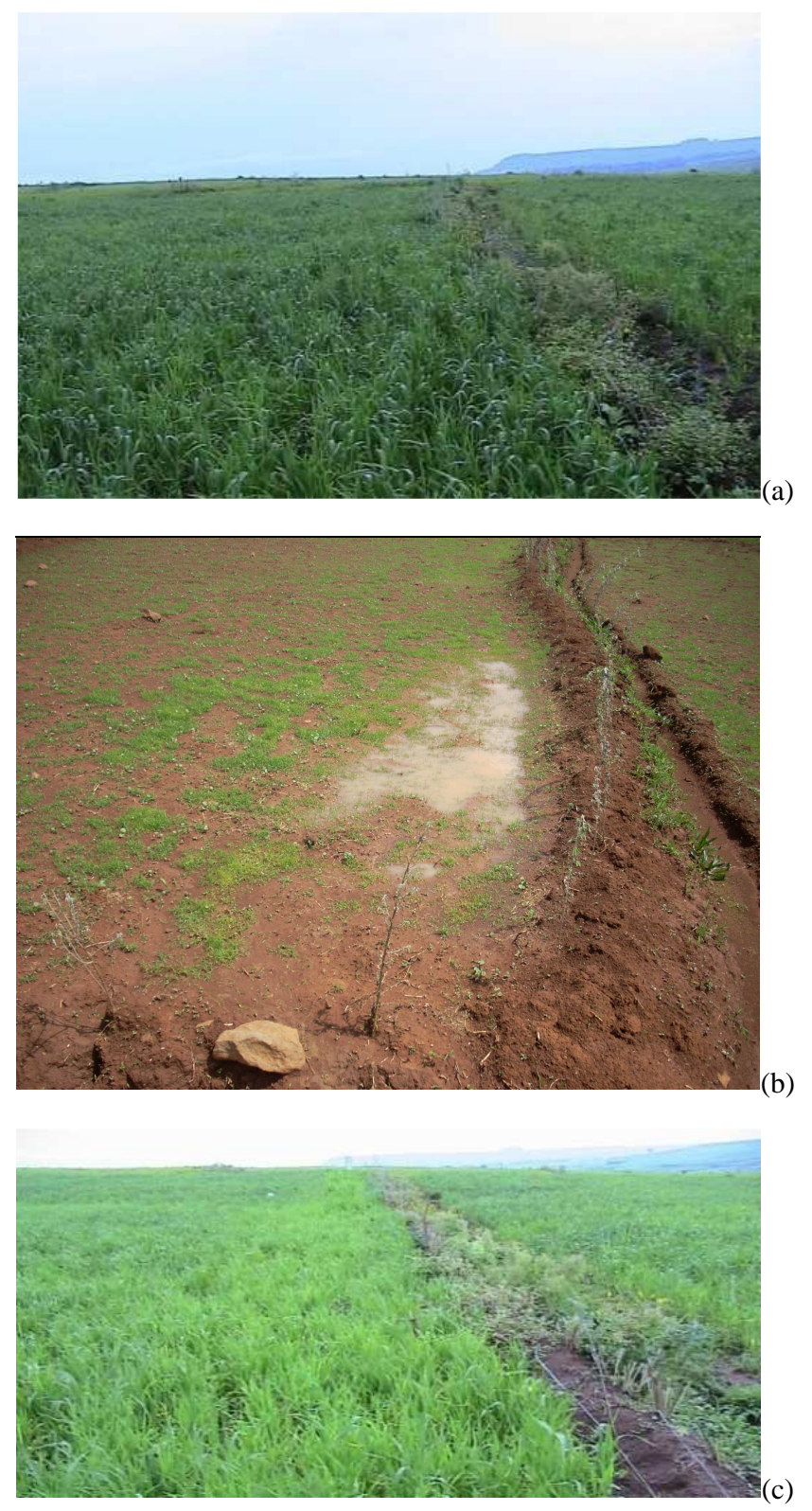

Fig. 8. Wheat fields: (a) conservation tillage (CT) fields are greener due to contour plowing and subsoiling, which reduced surface runoff in favor of infiltration, (b) traditional tillage (TT) fields has waterlogging behind SCS with yellowish color and stunted growth (c), generated more surface runoff that accumulated behind SCS causing water-logging. Picture taken at Enerata on 8 September 2010 (a,c) while (b) was taken on 26 July 2010.

it did to surface runoff. Treatment effects diminished as the season progressed due to reduced surface runoff and hence soil loss with increasing crop cover. In this study, measurements could only be made after sowing. Larger treatment differences could be observed before sowing and hence future research should include monitoring soil loss before sowing. 


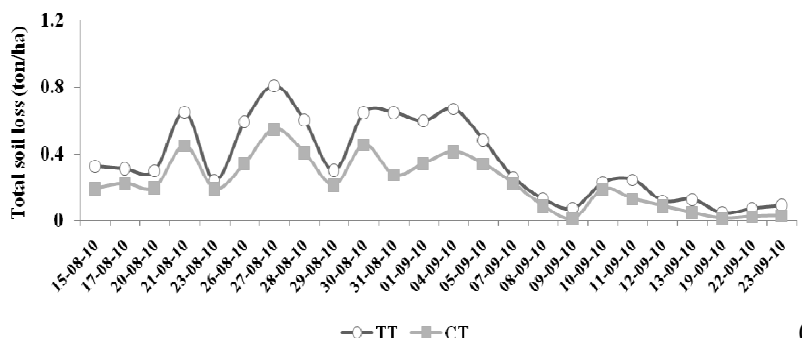

(a)

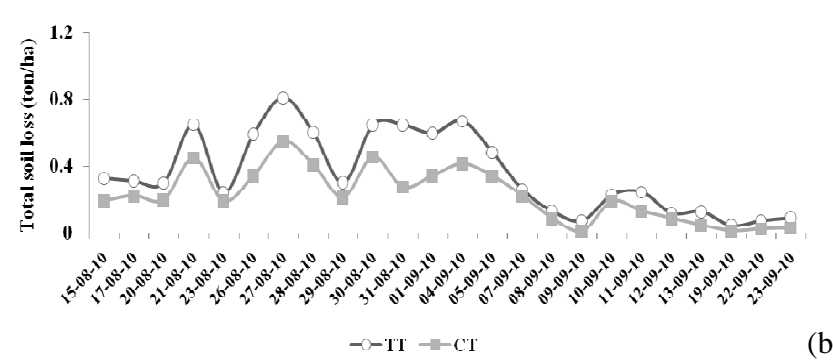

(b)

Fig. 9. Soil loss as affected by tillage treatment (a) wheat and (b) tef. Note the higher difference in wheat than in tef as influenced by seedbed compaction during tef planting and at earlier stage than at later due to reduced soil loss with increasing crop cover.

\subsection{Convenience in plowing between SCS}

One of the main problems associated with the adoption of SCS by farmers in Ethiopia is the inconvenience created to the tradition of cross plowing. Temesgen et al. (2008) have shown that the V-shaped furrow created by the Maresha plow is the main reason for traditional cross plowing. The winged subsoiler allows farmers to undertake consecutive tillage operations along the same line, in this case, parallel to the Fanya juus, because the wings cut the soil on the sides of the Vshaped furrow created by the Maresha plow. This makes it possible to control weeds between consecutive furrows by plowing only in one direction thereby making it convenient to plow in the presence of Fanya juus. During field interviews with farmers, those who practiced CT unanimously reported that the new tillage system is more convenient than TT in fields treated with Fanya juus.

\subsection{Agronomy}

The mean values of both biomass and grain yields from CT are higher than that from TT although the differences are not statistically significant at $\alpha=0.05$ (Table 3 ). This is due to high variation in soil fertility as replications were made in different farmers' fields. Participating farmers noted the differences in biomass and grain yield. According to the interviews, farmers believe the reasons could be (1) reduced soil erosion, (2) better weed control, (3) extended period of soil wetness, and (4) reduced water logging in CT. Farmers believe that reduced soil erosion in CT led to reduced loss of soil nutrients while retention of soil moisture in deeper layers
Table 3. Biomass and grain yield of wheat and tef from conservation and traditional tillage at Enerata, Ethiopia.

\begin{tabular}{llll}
\hline Crop type & Tillage & $\begin{array}{l}\text { Biomass } \\
\left(\mathrm{kg} \mathrm{ha}^{-1}\right)\end{array}$ & $\begin{array}{l}\text { Grain yield } \\
\left(\mathrm{kg} \mathrm{ha}^{-1}\right)\end{array}$ \\
\hline Wheat & CT & $5833( \pm 872) \mathrm{a}$ & $2685( \pm 462) \mathrm{b}$ \\
& TT & $4167( \pm 797) \mathrm{a}$ & $1985( \pm 245) \mathrm{b}$ \\
Tef & CT & $3960( \pm 340) \mathrm{a}$ & $2396( \pm 440) \mathrm{b}$ \\
& TT & $3470( \pm 429) \mathrm{a}$ & $1868( \pm 367) \mathrm{b}$ \\
\hline
\end{tabular}

Standard error of the mean in parenthesis. Values followed by dissimilar letters along a column are significantly different $(\alpha=0.05)$

extended the growing period. Field observations have also revealed deeper root growth in CT than in TT that could have increased crop water availability. Consequently, farmers harvested CT plots, on average, one week after harvesting TT plots. They believe this resulted in more biomass and grain yield. Reduced water-logging and hence better aeration in CT made the crop greener (Fig. 6a) compared to water-logged strips behind SCS in TT (Fig. 6b and c), which could contribute to increased biomass production in the former.

\section{Conclusions and recommendations}

Adoption of SCS in high rainfall areas in the upper Blue Nile (Abbay) river basin, in Ethiopia is constrained by reduced crop yield, accelerated soil erosion particularly due to frequent breaching of SCS, which in turn is caused by higher surface runoff from plowing up and down the slope. Waterlogging behind SCS and inconvenience to the tradition of cross plowing were reported to be constraints for adoption as well. In this experiment, it has been shown that integration of locally adapted conservation tillage system with SCS can reduce surface runoff leading to a reduction in soil loss. Waterlogging behind SCS was reduced and grain yields of wheat and tef were increased although the differences were not statistically significant $(\alpha=0.05)$, apparently due to high fertility variations among the experimental fields (replications). Farmers interviews showed that they are convinced that CT increased grain yield. They also reported increased convenience to plow between SCS. Farmers plan to continue using $\mathrm{CT}$ in the future. It is concluded that integration of $\mathrm{CT}$ with SCS can enhance performance and adoption of SCS in high rainfall areas of Ethiopia.

Further research needs to be undertaken to expand the data series spatially as well as temporally. Possibilities to reduce the number of plowing with CT and cost benefit analysis of the CT system have to be investigated. Reduced surface runoff with the application of CT opens the opportunity to increase bund spacing thereby addressing another complaint of farmers pertaining to loss of productive land. Future research should test CT with wider bund spacing than that recommended here. 
Upscaling of the locally adapted conservation tillage can improve adoption of soil conservation structures thereby reducing the current land degradation and siltation of reservoirs. Moreover, increased infiltration resulting in more soil water availability over a longer period of time would mean increased grain and biomass production in areas where moisture stress is a problem. Following additional tests in other areas to estimate yield advantages and soil conservation as well as cost benefit analysis, upscaling of the technology has to be considered in both humid and dry regions.

Acknowledgements. The study has been carried out as a project within a larger research program called "In search of sustainable catchments and basin-wide solidarities in the Blue Nile river Basin", which is funded by the Foundation for the Advancement of Tropical Research (WOTRO) of the Netherlands Organization for Scientific Research (NWO), UNESCO-IHE, Delft, the Netherlands and Addis Ababa University, Ethiopia. Desale Kidane and Habtamu Muche helped in collecting data during the main season of 2010 while Brhanu Biazin helped in analyzing data.

Edited by: A. Ghadouani

\section{References}

Bai, Z. G., Dent, D. L., Olsson, L., and Schaepman, M. E.: Global assessment of land degradation and improvement 1: identification by remote sensing, Report 2008/01, FAO/ISRIC, Rome/Wageningen, 2008.

Betrie, G. D., Mohamed, Y. A., van Griensven, A., and Srinivasan, R.: Sediment management modelling in the Blue Nile Basin using SWAT model, Hydrol. Earth Syst. Sci., 15, 807-818, doi:10.5194/hess-15-807-2011, 2011.

Bewket, W. and Sterk, G.: Dynamics in land cover and its effect on stream flow in the Chemoga watershed, Blue Nile basin, Ethiopia, Hydrol. Process., 19, 445-458, 2005.

Biazin, B., Stroosnijder, L., Temesgen, M., Abdulkadir, A., and Sterk, G.: The effect of Long-term maresha ploughing on soil physical properties in the central rift valley of Ethiopia, Soil Till. Res., 111, 115-122, 2011.

Busscher, W. J., Bauer, P. J., and Frederick, J. R.: Recompaction of a coastal loamy sand after deep tillage as a function of subsequent cumulative rainfall, Soil Till. Res., 68, 49-57, 2002.

FAO: Conservation Agriculture, http://www.fao.org/ag/ca/index. html (last access: 8 July 2008), 2008.

Gebreegziabher, T., Nyssen, J., Govaerts, B., Getnet, F., Behailu, M., Haile, M., and Deckers, J.: Contour furrows for in situ soil and water conservation, Tigray, Northern Ethiopia, Soil Till. Res., 103, 257-264, 2009.

Harris, G. L., Howse, K. R., and Pepper, T. J.: Effects of tooling and cultivation on soil-water and runoff from a drained clay soil, Agr. Water Manage., 23, 161-180, 1993.

Hengsdijk, H., Meijerink, G. W., and Mosugu, M. E.: Modeling the effect of three soil and water conservation practices in Tigray, Ethiopia, Agr. Ecosyst. Environ., 105, 29-40, 2005.
Herweg, K.: Problems of Acceptance and Adoption of Soil Conservation in Ethiopia, Trop. Appl.Resour. Manage., 3, 391-411, 1993.

Herweg, K. and Ludi, E.: The performance of selected soil and water conservation measures - case-studies from Ethiopia and Eritrea, Catena, 36, 99-114, 1999.

Hurni, H.: Land degradation, famines and resource scenarios in Ethiopia, in: World Soil Erosion and Conservation, edited by: Pimental, D., Cambridge, 27-62, 1993.

Julie, P.: SPSS Survival manual: A step by step guide to data analysis using SPSS for Windows Version 15, 3rd Edn., Open University Press, UK, 2007.

Makurira, H., Savenije, H. H. G., and Uhlenbrook, S.: Modelling field scale water partitioning using on-site observations in subSaharan rainfed agriculture, Hydrol. Earth Syst. Sci., 14, 627638, doi:10.5194/hess-14-627-2010, 2010.

McHugh, O., Tammo, S., Berihun, A., and Erick, C. M. F.: Performance of in situ rainwater Conservation tillage techniques on dry spell mitigation and erosion control in the drought-prone North Wello Zone of the Ethiopian highlands, Soil Till. Res., 97, 19-36, 2007.

MoWR - Ministry of Water Resources: Improvement of the resource-population sustainability balance. Water Resources Development, MoWR, Addis Ababa, Ethiopia, 1993.

MST - Ministry of Science and Technology: Improvements on traditional plough, Intellectual Property Gazette, No. ET/M/2007/425, Ethiopian Intellectual Property office, Ministry of Science and Technology, Addis Ababa, Ethiopia, 2008.

Musefa, A.: Hydrological responses to land cover changes; Modelling Case study in Abbay/Blue Nile basin, Ethiopia, MSc Thesis, ITC, Enschede, 2007.

Rowland, J. R. J. (Ed.): Dryland Farming in Africa, Macmillan Education Ltd. in cooperation with the CTA, Wageningen, The Netherlands, 145 pp., 1993.

Shiferaw, B. and Holden, S.: Soil Erosion and Smallholders' Conservation Decisions in the Highlands of Ethiopia, World Development, 27, 739-752, 1999.

Sojka, R. E., Westermann, D. T., Brown, M. J., and Meek, B. D.: Zone-subsoiling effects on infiltration, runoff, erosion, and yields of furrow-irrigated potatoes, Soil Till. Res., 25, 351-368, 1993.

Spaaks, J. H., Bouten, W., and McDonnell, J. J.: Iterative approach to modeling subsurface stormflow based on nonlinear, hillslopescale physics, Hydrol. Earth Syst. Sci. Discuss., 6, 5205-5241, doi:10.5194/hessd-6-5205-2009, 2009.

Taddese, G.: Land degradation: a challenge to Ethiopia, Environ. Manage., 27, 815-824, 2001.

Teklu, E. and Gezahegn, A.: Indigenous Knowledge and Practices for Soil and Water Management in East Wollega, Ethiopia, in: Technological and Institutional Innovations for Sustainable Rural Development, edited by: Wollny, C., Brodbeck, F., and Howe, I., Deutscher Tropentag 2003, 8-10 October 2003, Göttingen, www.tropentag.de, 2003.

Temesgen, M.: Conservation Tillage Systems and Water Productivity Implications for Smallholder Farmers in Semi-arid Ethiopia, PhD Thesis, Taylor \& Francis/Balkema, Leiden, The Netherlands, 2007.

Temesgen, M., Rockström, J., Savenije, H. H. G., Hoogmoed, W. B., and Alemu, D.: Determinants of tillage frequency among 
smallholder farmers in two semi-arid areas in Ethiopia, in: Physics and Chemistry of the Earth, University Press, Cambridge, 183-191, 2008.

Temesgen, M., Hoogmoed, W., Rockström, J., and Savenije, H. H. G.: Conservation Tillage Implements for Smallholder farmers in Semi-arid Ethiopia, Soil Till. Res. J., 104, 185-191, doi:10.1016/j.still.2008.10.026, 2009.
Tromp-van Meerveld, H. J. and McDonnell, J. J.: Threshold relations in subsurface stormflow: 2. The fill and spill hypothesis, Water Resour. Res., 42, W02411, doi:10.1029/2004WR003800, 2006. 